\title{
Transisi kelembagaan dan isi siaran radio PEMDA menjadi radio publik lokal di Jawa Timur
}

\author{
Institutional transition and public radio broadcast content in East \\ Java
}

\author{
Surokim \& Tatag Handaka \\ Program Studi Ilmu Komunikasi, Fakultas Ilmu Sosial dan Ilmu Budaya, Universitas Trunojoyo \\ Jalan Raya Telang P.O. BOX 2, Kamal, Bangkalan 69162. Telp (031)3011146,081330683681. \\ E-mail: surochiemabdussalam@yahoo.com
}

\begin{abstract}
The existence of Local Government Radio (namely Radio Khusus Pemerintah Daerah, abbreviated as RKPD) in East Java Province, Indonesia faced many problems in post implementing of Broadcasting Act No. 32/2002. This study used constructivism paradigm. The method used in this research is descriptive research with qualitative analysis. This research conducted observation, indepth interview, limited discussion to collect data; complemented with secondary data. The research uses purposive sampling technique. The data analyzed along with data interpretation and narrative report writing. By the research, it is found that RKPD faced complex problems regarding transition of both institutions and broadcasting content programs. Until recent time, RKPD did not have a standard design to be a public radio, both in the institutional aspect and broadcasting content program. In fact, there were various types of institution and legal entities as result of interpreting the act. The Broadcasting content program was also still dominated by the government interest. The program also discussed public issues minimally and gave limited access for the public to participate and engage. Institutional design and broadcasting program should be designed according to act No. 32/2002 as public radio that reflected the interests of public and supporting of public service.
\end{abstract}

Keywords: design of transition, institutional, broadcasting, radio, East Java

\begin{abstract}
Abstrak
Eksistensi Radio Pemerintah Daerah yang harus beralih menjadi radio untuk publik, belum ada kejelasan. Proses transisi radio mengalami berbagai situasi rumit dan problematik. Metode penelitian ini menggunakan paradigma konstruktivisme (constructivism paradigm). Teknik pengumpulan data primer meliputi observasi, wawancara/indepth interview, diskusi terbatas, dan dilengkapi dengan data sekunder. Teknik sampling yang digunakan adalah purposif (purposive sampling). Analisis data dilakukan bersamaan dengan pengumpulan data, interpretasi data, dan penulisan laporan naratif. Hasil penelitian menunjukkan bahwa RKPD menghadapi masalah yang kompleks, menyangkut transisi kedua lembaga penyiaran dan program konten. Sampai sekarang RKPD tidak memiliki desain standar untuk menjadi radio publik di kedua lembaga dan Program konten penyiaran. Bahkan, ada berbagai macam institusi dan badan hukum akibat menafsirkan tindakan. Program konten Penyiaran juga masih didominasi oleh kepentingan pemerintah. Program ini juga membahas isu-isu publik minimal dan memberikan akses terbatas bagi publik untuk berpartisipasi dan terlibat masuk desain kelembagaan dan penyiaran program harus dirancang sesuai untuk bertindak No 32/2002 sebagai radio publik yang mencerminkan kepentingan masyarakat dan mendukung pelayanan publik.
\end{abstract}

Kata kunci: penyiaran, radio, Jawa timur, desain transisi, kelembagaan 


\section{Pendahuluan}

Eksistensi Radio Khusus Pemerintah Daerah (RKPD) di Jawa Timur mulai dipertanyakan dan menjadi bahan diskusi yang menarik sejak UU Penyiaran No. 32/2002 disahkan. Situasi menjadi rumit dan problematik mengingat hingga kini belum ada kejelasan ke arah mana transisi radio milik pemerintah daerah tersebut. Menurut catatan Komisi Penyiaran Indonesia Daerah Jawa Timur hingga hingga 2011 belum ada radio pemerintah daerah yang mampu menyelesaikan transisi secara tuntas sebagaimana diamanatkan UU No. 32/2002. Undang-undang Penyiaran No. 32/2002 memang tidak mengakomodasi eksistensi radio (milik) pemerintah sehingga RKPD harus menyesuaikan diri menjadi salah satu jenis radio yakni radio swasta, komunitas, publik, atau berlangganan. Saat ini, pengelola RKPD di berbagai daerah di Jawa Timur masih sedang dalam proses transformasi dan mencari bentuk adaptasi kelembagaan yang tepat. Namun, banyak kendala dan tantangan yang harus dihadapi dalam proses transformasi kelembagaan dan isi siaran tersebut.

Desain transisi ini penting untuk dibuat sebagai tindak lanjut penataan lembaga penyiaran di daerah yang sedang carut-marut saat ini. Tiadanya kejelasan mengenai perubahan kelembagaan dan isi siaran membuat penataan lembaga penyiaran semakin rumit dan problematik. Penelitian ini strategis sebagai langkah awal untuk mendapatkan kejelasan dan roadmap penataan radio publik di daerah dalam rangka penyesuaian dan pelaksanaan dalam UU Penyiaran 32/2002.

Penelitian ini menjawab bagaimana kondisi faktual keberadaan radio milik pemerintah daerah (RKPD) di Jawa Timur dan sejauh mana persiapan serta perkembangan keberadaan radio milik pemerintah tersebut menjadi radio publik dan bagaimana desain transisi radio pemerintah daerah menjadi radio publik di Jawa Timur sesuai dengan UU 32/2002.

\section{Metode Penelitian}

Metode penelitian ini menggunakan paradigma konstruktivisme (constructivism paradigm). Jenis penelitian ini adalah kualitatif, yang mendasarkan diri pada aspek reflective. Kedudukan suatu penelitian bersifat menggali interpretasi subyek (Denzin 1994). Metode penelitian yang digunakan adalah deskriptif. Metode deskriptif menitikberatkan pada observasi dan suasana alamiah (naturalistics setting). Peneliti bertindak sebagai pengamat yang membuat kategori perilaku, mengamati gejala, dan mencatatnya secara cermat. Penelitian deskriptif tidak hanya menjabarkan/analitis, tetapi juga memadukan/sintetis. Selain itu, juga tidak hanya melakukan klasifikasi, tetapi juga mengorganisasi (Moleong 1999). Teknik pengumpulan data primer meliputi observasi, wawancara/indepth interview, diskusi terbatas, dan dilengkapi dengan data sekunder.

Teknik sampling yang digunakan adalah purposif (purposive sampling). Analisis data dilakukan bersamaan dengan pengumpulan data, interpretasi data, dan penulisan laporan naratif. Peneliti melakukan pembuktian untuk memastikan keabsahan internal, dengan melakukan strategi trianggulasi sumber, data, dan teori. Alat analisis utama yang digunakan adalah teori ruang publik (public sphere). Objek dan lokasi riset ini adalah radio RKPD di wilayah Jawa Timur.

\section{Hasil dan Pembahasan}

\section{Kelembagaan/struktur}

Kedudukan hukum LPP Lokal dapat diketahui mulai dari ketentuan fundamental hingga ketentuan teknis. Sebagaimana disebutkan dalam UU 32/2002 dan PP No. 11/2005 lembaga penyiaran publik adalah bersifat Independen, netral, dan non komersial.

Lembaga penyiaran publik sebagaimana tersebut dalam Pasal 14 ayat 3 dan 4 UU 32/2002 meliputi RRI, TVRI, dan LPPL. Dengan demikian di daerah provinsi, kabupaten atau kota dapat didirikan lembaga penyiaran publik lokal. Hal ini yang menjadi pijakan dasar atas keberadaan LPPL. 
Pengertian LPP Lokal kemudian diperluas dalam PP No. 11 Tahun 2005 sebagai lembaga penyiaran yang berbadan hukum yang didirikan oleh pemerintah daerah, menyelenggarakan kegiatan penyiaran radio atau penyiaran televisi, bersifat independen, netral, tidak komersial dan berfungsi memberikan layanan untuk kepentingan masyarakat yang siarannya berjaringan dengan radio republik Indonesia (RRI) untuk radio dan Televis Republik Indonesia (TVRI).

Terkait transisi kelembagaan, RKPD dapat menjadi badan publik melalui persetujuan DPRD dalam bentuk perda. Namun, dalam praktiknya proses pembentukan perda sendiri membutuhkan waktu yang cukup lama dan berbelit-belit. Apalagi jika perda tersebut yang tidak memiliki implikasi ekonomis bagi daerah biasanya proses pembahasannya akan membutuhkan waktu yang lama (Salman 2011).

Dalam kaitan dengan pembentukan LPPL menurut Informan (1) ketentuan yang menyebut 'dapat didirikan' bisa menimbulkan beragam tafsir. Sebagaimana disebut dalam PP bahwa di daerah provinsi, kabupaten, atau kota dapat didirikan LPPL. Dapat atau boleh mendirikan radio/televisi berarti boleh juga kalau daerah tidak membuat. 'Dapat didirikan' dengan demikian sebenarnya pendirian LPPL sifatnya tentatif sesuai kebutuhan jika masyarakat belum bisa menerima siaran RRI.

Dalam ketentuan penutup tambah informan (1) juga disebutkan bahwa penyelenggaraan penyiaran radio yang didirikan atau dimiliki pemerintah daerah yang telah ada dan beroperasi sebelum ditetapkannya Peraturan Pemerintah ini dan memilih menjadi LPPL, wajib melakukan penyesuaian dengan ketentuan Peraturan Pemerintah dalam jangka waktu paling lama 1 (satu) tahun sejak diberlakukannya Peraturan Pemerintah tentang LPP.

Pilihan menjadi badan hukum publik, menurut informan (1) adalah tepat untuk kepentingan pelayanan publik. Sebagaimana di jelaskan di bawah ini:

"Pada dasarnya subjek hukum (legal subject) adalah setiap pembawa atau penyandang hak dan kewajiban dalam hubungan-hubungan hukum. Subjek hukum dapat merupakan orang atau natuurlijkperson (menselikperson) dan bukan orang (reshtsperson). Rechtperson biasa disebut badan hukum yang merupakan persona ficta atau orang yang diciptakan oleh hukum sebagai persona (dalam teori fiksi)"

"Adapun Badan hukum publik dapat dikatakan sebagai badan hukum publik apabila kepentingan yang menyebabkan badan itu dibentuk didasarkan atas kepentingan umum atau kepentingan publik. Ada kepentingan publik yang dinyatakan dalam informasi, juga badan hukum publik"

Ketentuan mengenai Badan Hukum Publik adalah 1) Badan Hukum yang mewakili kepentingan umum dan menjalankan aktivitas di bidang hukum publik, 2) Badan hukum yang mewakili kepentingan publik dan menjalankan aktivitas di bidang hukum keperdataan.

Prosedur pendirian LPPL sebagai Badan Hukum publik, sebagaimana dijelaskan dalam peraturan pemerintah meliputi: 1) didirikan oleh pemerintah daerah (Provinsi/ Kabupaten/Kota), 2) dengan persetujuan DPRD. Problem awal menyangkut 'persetujuan' DPRD dalam pendirian LPPL ini juga problematik. Hal ini menurut informan 1 terkait dengan tafsir mengenai persetujuan DPRD sebagai syarat final atau syarat antara. Bentuk hukum persetujuan dengan DPRD menurut informan (1) perlu ditegaskan secara jelas. Jika Perda sebagai 'AKTA' Pendirian LPPL, maka hal ini akan terkait dengan (1) Pembentukan kelembagaan (2) Penggunaan Sumber Daya: Keuangan, SDM (3) Persetujuan DPRD.

Sekadar sebagai perbandingan informan (1) mengemukakan bahwa hingga saat ini sudah banyak Peraturan Perundang-undangan yang dijadikan sebagai "AKTA" Pendirian Badan Hukum di antaranya (1) Bank Indonesia (UUD 1945, UU BI), (2) BHMN (PP No. 30 Tahun 2005 tentang Penetapan Universitas Airlangga sebagai BHMN), (3) BP Migas (UU Migas), (4) BUMD.

Terkait dengan sinkronisasi aturan pada dasarnya, substansi perda pembentukan LPP Lokal 1) melakukan ketentuan Peraturan perundang-undangan yang lebih tinggi; dan 2) mengatur ketentuan 
yang tidak diatur dalam peraturan yang lebih tinggi sepanjang tidak bertentangan dengan Peraturan Perundang-undangan.

Sebagaimana dijelaskan informan (1) di bawah ini:

"Kalo sudah ada PERDA yang membentuk LPPL maka secara kelembagaan sudah dianggap sah secara hukum, tidak diperlukan langkah hukum lainnya, Depkumham hanya untuk PT, cukup LPPL dinyatakan sah adanya, Nah, selanjutnya struktur kelembagaan harus sesuai dengan aturan yakni harus dipilih dewan pengawas dan dewan direksi, pembiayaan ini, dana APBD memiliki konstribusi sangat besar untuk perbiayaan."

"Terkait sumber pembiayaan maka negara dalam hal ini pemerintah daerah wajib merencanakan alokasi anggaran untuk LPL yang akan dikelola melalui SKPD sebagaimana selama ini berlaku di lembaga auxilary state."

"Keberadaan supporting organ administratif sangat penting untuk mengelola keuangan. Maka konsen selanjutnya adalah mendorong profesionalisme pengelola keuangan yang bisa merencanakan anggaran dan kuangan dari APBD."

Dengan demikian keberadaan Perda sangat penting sebagai dasar bagi pembentukan badan hukum publik LPPL. Selain itu ada syarat pokok pendirian LPPL di daerah. Menurut menurut informan (2) sebagaimana disebut dalam PP No 11/2005 adalah 1) belum ada stasiun RRI/TVRI (perkecualian jika ada LPPL lebih dulu). 2) RKPD juga harus mampu menyelenggarakan siaran 12 jam secara berkesinambungan. Di samping itu sebagai bentuk pertanggungjawaban publik, pengelola LPPL juga harus membuat laporan kepada publik.

"LPPL akan diprioritaskan dalam mendapatkan kanal frekuensi jika di daerah tersebut tidak ada RRI dan sepanjang bisa menyelenggarakan siaran 12 jam secara berkesinambungan."

"LPPL juga wajib membuat laporan tahunan kepada publik melalui DPRD sebagai bentuk akuntabilitas."

"Secara administratif karena LPPL menerima dana APBD maka laporan itu disampaikan kepada kepala daerah. Selain itu, secara politis karena keberadaan lembaga ini adalah independen dan ada unsur keterwakilan publik maka LPPL juga harus melaporkan kepada masyarakat"

Konsekuensi logis agar LPPL dapat menjalankan peran secara profesional maka LPPL harus melakukan persiapan dan pengembangan kapasitas diri. Adapun yang harus dilakukan ke depan adalah 1) pelatihan manajemen/program radio publik 2) segera membahas Perda: legalitas keberadaan LPPL, pembentukan dewan pengawas \& direksi 3) administrasi-Keuangan pada Sekretariat LPPL berupa SKPD (mirip sekretariat badan kuasi negara) 4) penegasan badan hukum: sebagai lembaga penyiaran publik lokal (Bukan BUMD, UPT, apalagi PT) 5) karakter khas publik pada format program siaran (Santoso 2009).

Temuan di Jawa Timur menyangkut keberagaman dalam transisi kelembagaan antara lain: 1) RKPD Tuban Berubah Menjadi BUMD 2) RKBD Situbondo berubah menjadi Swasta 3) RKPD JT FM di bawah Diskominfo 4) RPKD Lamongan di bawah Humas dan Protokol 5) RKPD Sampang di bawah Dinas Perhubungan. Sebagian besar RKPD juga menjadi unit pelaksana teknis daerah. Dengan banyaknya jenis kelembagaan ini maka transisi RKPD masih dipahami berbeda-beda dan hingga kini belum ada kesatuan arah sebagai panduan bersama.

Sebagai badan publik maka bentuk kelembagaan yang memungkinkan adalah seperti model badan kuasi/auxilary state. LPP akan ada dewan pengawas dan pelaksana yang didukung kesekretariatan yang memungkinkan mengelola alokasi dana dari negara. 


\section{Badan hukum publik}

Transisi RKPD dianggap lebih dekat ke jenis radio publik mengingat RKPD mengklaim sebagai radio yang bertujuan untuk memenuhi kebutuhan publik secara luas dalam informasi, hiburan, dan pendidikan. Sejalan dengan visi seperti ini maka radio publik harus melayani warga secara luas. Hal ini yang membuat LPPL tidak menjadi radio komunitas mengingat daya jangkau yang terbatas yakni hanya sejauh 2,5 kilometer udara. RKPD juga tidak menjadi radio swasta dan berlangganan karena misinya adalah untuk melayani publik dan tidak mengejar keuntungan (nonkomersial). Pilihan yang ada adalah menjadi radio publik yang fokus pada public service.

Pemda dapat melihat contoh transisi di RRI yang telah berubah menjadi radio publik. Pengelolaannya dilakukan oleh dewan pengawas yang dipilih DPR RI dan dewan direksi yang dipilih oleh dewan pengawas. Mengingat pentingnya keberadaan radio publik dalam memenuhi kebutuhan semua lapisan masyarakat maka pemerintah pusat harus menyediakan alokasi frekuensi bagi radio jenis ini. Apalagi, pemerintah telah bertekad akan menjamin tumbuhnya radio publik di daerah. Komitmen ini tertuang dalam peraturan pemerintah No. 11 Tahun 2005 tentang penyelenggaraan penyiaran lembaga penyiaran publik.

Sebagai langkah awal maka Kepala Daerah Gubernur/ Bupati/ Walikota membuat Surat Keputusan yang berisi Keputusan tentang perubahan status dari Radio Pemerintah menjadi radio publik lokal (RPL). Pada tahap internal dilanjutkan dengan penyiapan tim transisi untuk penyesuaian struktur organisasi dan tata kelembagaan untuk mengisi posisi dan dukungan keuangan sesuai peraturan LPPL. Tugas selanjutnya adalah penyusunan usulan Draf PERDA LPPL oleh biro hukum melalui konsultasi dan uji publik untuk kemudian diajukan ke DPRD. Melalui pembahasan di dewan maka akan menjadi PERDA LPPL dan sah menjadi badan hukum publik.

\section{Bagan 1.}

Tahapan pembentukan radio publik (LPPL)

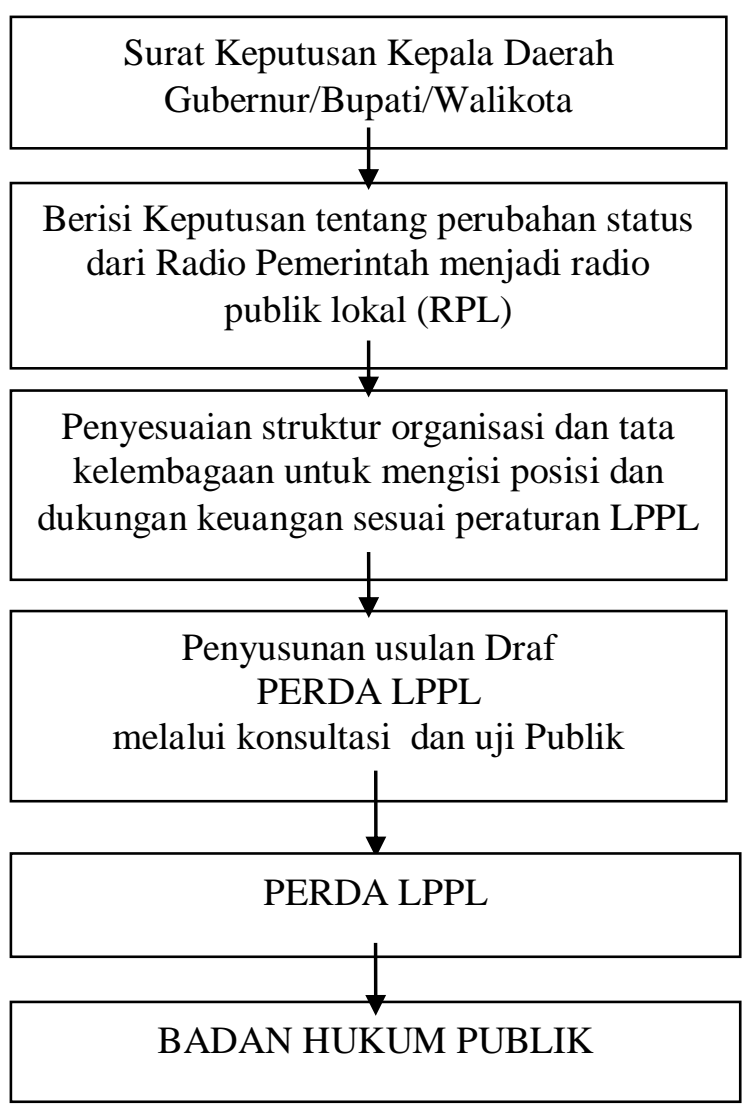


Sebagai badan publik maka supervisi publik menjadi penting sebagai representasi atas daulat dan kontrol masyarakat. Di sinilah letak penting adanya dewan pengawas yang diambil dari unsur publik yang memegang otoritas penuh dalam penyusunan kebijakan dan arah program radio. Melalui pengawasan publik diharapkan dapat mendudukkan diri di atas semua kepentingan stakeholders penyiaran. Perannya lebih difokuskan bagi kepentingan dan kemaslahatan publik.

Perubahan ini sejalan dengan pandangan Irianto (2011) bahwa organisasi publik harus responsif untuk beradaptasi dengan lingkungan termasuk di dalamnya melalui perubahan manajemen dengan konvergensi peran yang lebih substantif. Dalam konteks ini adalah perubahan peran kelembagaan yang lebih beroreintasi pada pelayanan publik.

\section{Isi siaran}

Radio khusus pemerintah daerah di Jawa Timur masih belum mampu melepaskan diri dari ciri khas awal sebagai radio milik pemerintah. Menurut informan (3) sebagian besar program acara masih merepresentasikan program dan kepentingan pemerintah. Ciri khas sebagai radio publik masih belum terlihat. Bahkan tidak ada posititoning, program acara radio hampir sama dengan program yang dimiliki radio swasta pada umumnya. Program acara sebagian besar masih dominan kepentingan pemerintah dan belum menjadi wadah aspirasi kepentingan, aspirasi dan pemberdayaan publik.

Program acara lokal yang menjadi kekuatan dan ciri khas radio publik menurut informan (3) juga masih belum sepenuhnya merepresentasikan budaya lokal. Bahkan banyak ditemukan program acara mengikuti kehendak pasar dan budaya baru, khususnya metropolitan dan asing (western) seperti terjadi di RKPD di berbagai daerah baik dalam siaran kata maupun musik. Hal ini tergambar dalam program siaran hiburan dan siaran kata yang terjadi merata di semua radio milik pemerintah di Jawa Timur. Sebagai radio publik, RKPD masih kecil di bawah 30\% untuk siaran bermuatan budaya lokal.

Menurut informan (3) representasi kultural Jawa Timur dengan budaya Pandalungan, Mataraman, Madura, dan Arek dengan tipologi masyarakat yang didominasi masyarakat agraris yang relegius dan budaya jawa belum jelas terlihat dan tergambar dalam siaran lokal. Bahkan di berbagai daerah siaran kata dan musik lebih dominan budaya kontemporer metropolitan dan budaya barat.

\section{Representasi budaya Jawa Timur}

Program siaran radio publik semestinya mencerminkan gambaran budaya lokal sebagai identitas lokal. Adapun gambaran budaya Jawa Timur meliputi Pandalungan, Mataraman, Madura, Arek, dan Pantura.

Budaya pandalungan yang dapat dikembangkan dalam siaran adalah tentang kondisi sosiokultural masyarakat santri, dan sebagian besar dari aliran Ahlisunnah wal jamaah, perpaduan masyarakat pesisir dan agraris. Pekerja keras, kekerabatan yang kental, dan mobilitas yang tinggi, serta dorongan kuat untuk mendapat hiburan. Hiburan utama yang diharapkan masyarakat melalui radio adalah musik. Masyarakat pesisir menggemari lagu dangdut, khususnya dangdut dengan corak Madura. Program pendidikan budaya meliputi kegiatan pesantren, seni musik hadrah, campursari, dan festival hadrah.

Adapun gambaran budaya Mataraman dicirikan dengan kondisi sosiokultural masyarakat agraris, budaya Jawa halus, sebagaimana tipologi masyarakat Jawa dalam Cliford Getz bahwa masyarakat Mataraman juga terdiri atas santri, abangan dengan kekerabatan yang perpaduan masyarakat pesisir dan agraris. Kuatnya ikatan budaya Jawa Kulonan dengan memegang teguh budaya, adat, dan kebutuhan hiburan khas budaya Jawa. Acara macapat dan hiburan wayang kulit dan juga tokoh adat dan agama. 
Budaya Madura meliputi masyarakat yang religius dengan ketaatan yang tinggi terhadap para tokoh agama. Tokoh agama dalam hal ini kiai memegang peran sentral dalam masyarakat. Sebagian besar mengikuti aliran Ahlisunnah wal jamaah, perpaduan masyarakat pesisir dan perbukitan. Gaya hidup cenderung konsumtif, patron keluarga yang kuat, dan mobilitas ke luar daerah yang tinggi. Hiburan utama yang diharapkan masyarakat melalui radio adalah musik. Siaran menggunakan bahasa lokal.

Sementara itu budaya metro di beberapa kota besar cenderung dominan memengaruhi siaran radio di berbagai daerah. Gambaran masyarakat kelas menengah atas dengan trend konsumtif, kohesivitas yang rendah, dan mobilitas tinggi. Budaya metro yang individualis dan memiliki kebutuhan akan keberagaman dalam hiburan sesuai segmennya yang khusus. Isi siaran menyangkut hiburan, informasi dan pendidikan masyarakat, problematika dan solusi masalah perkotaan.

Selain itu budaya pantura yang bercirikan masyarakat yang religius, temperamental, sebagian besar menjadi nelayan dan memiliki mobilitas tinggi. Masyarakat pantura amat sensitif terhadap konflik. Kebutuhan hiburan cukup besar untuk menemani mereka dalam waktu luang, khususnya saat mempberaiki alat tangkap, isi siaran hiburan musik aspirasi masyarakat.

Menilik budaya lokal di atas, maka isi siaran radio publik LPPL diharapkan 1) siaran dapat merepresentasikan budaya lokal sebagai benteng sekaligus pelestari budaya agar masyarakat tidak tercerabut dari budaya asal (lokal), 2) siaran dapat menjangkau segmen masyarakat yang lebih luas dengan menghadirkan siaran yang bisa mendorong warga terlibat secara aktif dan radio dapat berfungsi sebagai ruang publik tempat masyarakat mendiskusikan persoalan-persoalan mutakhir yang dihadapi, 3) masyarakat sebenarnya juga sedang mencari alternatif di luar media arus utama (main stream) maka radio publik harus mampu menangkap kebutuhan itu agar menjadi alternatif untuk dapat memenuhi kebutuhan dan harapan pendengar, 4) radio harus mampu menjembatani kepentingan publik dengan pemerintah bukan hanya membenarkan dan ajang sosialisasi program pemerintah dan mampu memberikan wadah bagi masyarakat umum untuk menyampaikan aspirasinya sehingga dapat terjadi dialog yang timbal balik (2 arah).

\section{Isi siaran propublik}

Isi siaran LPPL harus mencerminkan kepentingan publik dan benar-benar didasarkan atas kebutuhan publik (public's need) bukan sekadar yang diinginkan publik (public's want). Program siaran harus mencerminkan kepentingan publik (representasi suara publik). Tidak hanya representasi publik, tetapi juga sebagai benteng pertahanan budaya lokal.

Transisi ini bisa dimulai dengan menjadikan LPPL sebagai media komunikasi masyarakat dengan berbagai lembaga pelayanan publik. Masyarakat bisa mendapatkan informasi terkait dengan problematika yang sedang dihadapi dan radio mampu menjembatani kepentingan itu dengan mempertemukan para pihak terkait melalui siaran.

Sebagai bentuk penguatan peran publik maka LPPL dapat membangun Local Consultative Forum (Ghazali 2003:51). LCF merupakan suatu forum untuk mendiskusikan tentang penyiaran dan mengajak masyarakat dalam penggalangan dana publik, perencanaan, dan produksi program. Forum LCF ini akan dapat menjadi partner sekaligus wahana yang mampu menjembatani apa saja kepentingan masyarakat dalam media publik. Publik akan turut memiliki media dan dengan sukarela akan membentuk kelompok-kelompok pendengar. Kelompok pendengar ini yang akan menjadi penyampai aspirasi dan harus didorong aktif menyalurkan aspirasinya terhadap keberadaan radio. Aspirasi yang disampaikan yang kemudian akan menentukan format dan program siaran yang akan dipancarluaskan oleh radio publik.

Sejatinya, radio publik harus menjadi sebuah ruang tempat berdialognya semua komponen yang ada di masyarakat. Misalnya, bila pemerintah daerah ingin mengeluarkan sebuah kebijakan menaikkan ongkos angkutan kota maka radio bisa menyediakan ruang publik untuk berdialog bagi pemerintah dan kelompok masyarakat yang akan terkena dampak kebijakan tersebut. 
Dalam ruang itu, pemerintah dan masyarakat dapat berdebat secara terbuka perihal kebijakan yang akan terbit itu. Hal ini sejalan dengan konsep public sphere Habermas dalam Wuryanta (2006) sebagai ruang otonom di antara negara (state), dan civil society, di mana setiap warga negara bisa melibatkan diri dalam diskursus tentang masalah bersama dan untuk mengontrol negara dan pasar. Celah tersebut dapat diisi dan diperankan oleh media massa yang berfungsi kepublikan yang memasok dan menyebarluaskan informasi yang diperlukan untuk penentuan sikap dalam masyarakat. Dalam konteks ini, penyiaran publik juga memfasilitasi pembentukan opini publik dengan menempatkan dirinya sebagai wadah independen untuk perdebatan publik, menyangkut isu ekonomi, politik, sosial, dan budaya.

Dalam masyarakat yang demokratis, penyediaan ruang publik yang bebas merupakan sebuah keniscayaan. Tersedianya ruang publik yang menjadi tempat pertemuan aneka gagasan yang dilontarkan anggota masyarakat akan membentuk masyarakat menjadi cerdas dan peduli terhadap ruang sosialnya. Melalui LPPL masyarakat bisa melakukan diskusi yang rasional, membentuk opini, menjalankan pengawasan terhadap negara.

Terkait dengan isi siaran LPPL sebagai media publik maka format isi siaran siaran dapat merepresentasikan budaya lokal sebagai benteng sekaligus pelestari budaya agar masyarakat tidak tercerabut dari budaya asal (lokal). Siaran dapat menjangkau segmen masyarakat yang lebih luas dengan menghadirkan siaran yang bisa mendorong warga terlibat secara aktif dan Radio dapat berfungsi sebagai ruang publik tempat masyarakat mendiskusikan persoalan-persoalan mutakhir yang dihadapi.

Tren saat ini terkait dengan media habit, masyarakat sebenarnya juga sedang mencari alternatif di luar media arus utama (main stream) maka radio publik dapat menangkap kebutuhan itu agar menjadi alternatif untuk dapat memenuhi kebutuhan dan harapan pendengar (Maryani 2011). Sebagai radio publik, LPPL harus mampu menjembatani kepentingan publik dengan pemerintah bukan hanya membenarkan dan ajang sosialisasi program pemerintah dan mampu memberikan wadah bagi masyarakat umum untuk menyampaikan aspirasi, kepentingan dan akan terjadi dialog dua arah yang sehat.

Lembaga penyiaran ini tidak semata-mata memproduksi acara siaran sesuai tuntutan liberalisasi dan selera pasar, serta bukan pula sebagai media pemerintah, melainkan berfungsi memberikan layanan untuk kepentingan masyarakat. Keberadaan lembaga penyiaran publik dimaksudkan untuk bisa membuka ruang publik (public sphere) dengan memberikan hak memperoleh informasi yang benar (right to know), dan menyampaikan pendapat atau aspirasi (right to express) bagi masyarakat, sehingga masyarakat sebagai warga negara dan subyek penyiaran yang pada gilirannya dapat berpartisipasi aktif dalam bidang penyiaran (Sudibyo 2004).

Hal ini sejalan dengan perkembangan demokrasi, keterbukaan publik, dan kemajuan teknologi serta dinamika masyarakat. Keberadaan radio publik diperlukan untuk memberikan keseimbangan dalam memperoleh informasi, pendidikan, kebudayaan, dan hiburan yang sehat pada masyarakat, diperlukan lembaga penyiaran publik yang bersifat independen, netral, tidak komersial (Masduki 2003).

Pengembangan LPPL juga selaras dengan pengalaman pengembangan media publik di berbagai negara seperti dalam proyek Unesco tahun 2001 bahwa lembaga penyiaran publik dapat menjadi media alternatif di tengah dominasi media kapitalis dan media pemerintah. Lebih dari itu diharapkan media publik dapat menjadi pengawas sosial (social surveillance). 
Bagan 2.

Desain transisi kelembagaan dan isi siaran

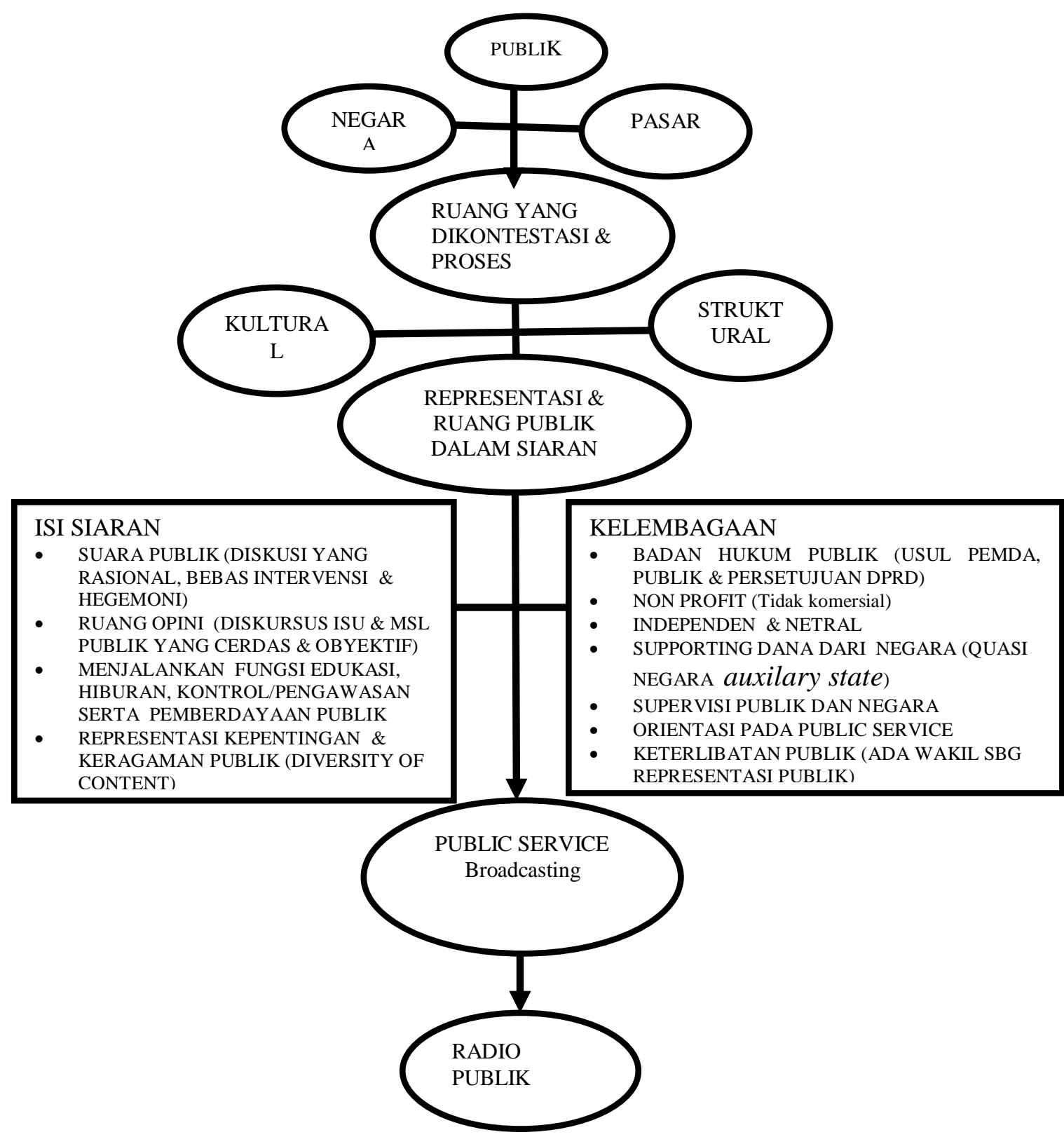

\section{Simpulan}

Dalam aspek kelembagaan, RKPD harus merubah diri menjadi lembaga penyiaran publik (LPPL) dengan bentuk badan hukum publik melalui Perda. Badan hukum publik memungkinkan adanya partisipasi dan supervisi publik yang akan turut terlibat dan menjadi pengawas dan pelaksana dalam pengelolaan radio publik. Hasil penelitian menunjukkan bahwa radio pemerintah di Jawa Timur belum memiliki desain yang baku untuk merubah diri menjadi radio publik. Hal ini dapat dilihat dari beragamnya jenis badan hukum yang dipilih di antaranya menjadi BUMD, lembaga swasta, UPT Teknis, Unit di bawah dinas pemerintah seperti: dinas Informasi, dinas perhubungan, dan 
sekretaria/protokoler Pemda. Badan hukum publik akan membawa implikasi pada aspek teknis pendanaan dan pengelolaan organisasi yang independen, netral, dan menjamin good governance.

Dalam aspek Isi siaran, RKPD sebagian besar masih mencerminkan suara dan kepentingan pemerintah dan belum mampu menjadi ruang publik yang fokus pada pelayanan publik dan agendaagenda publik. Selama ini isi siaran RKPD masih menjadi suara pemerintah daerah dan sebagai media sosialiasi kegiatan dan program pemeintah belum menjadi ruang diskusi, aspirasi, dan perbincangan mengenai berbagai masalah dan solusi yang dihadapi masyarakat. Isi siaran harus mencerminkan kepentingan publik dan konstruksi pada kebutuhan publik yang bertumpu pada kepentingan publik (PICON-public interest, importance, convenience, and necessity).

Desain transisi kelembagaan dan isi siaran difokuskan sesuai dengan amanat UU No. 32/2002 sebagai badan hukum lembaga penyiaran publik dan isi siaran yang fokus pada kepentingan dan pelayanan publik.

\section{Daftar Pustaka}

Denzin NK and Lincoln YS (1994) Handbook of Qualitative Research. London: Thousand Oaks.

Gazali E (2003) Konstruksi Sosial Industri Penyiaran: Acuan tentang Penyiaran Publik dan Komunitas. Jakarta: Departemen Ilmu Komunikasi FISIP Universitas Indonesia.

Irianto J (2011) Manajemen sumber daya manusia sektor publik di Indonesia: pengantar pengembangan model MSDM sektor publik. Jurnal Masyarakat, Kebudayaan dan Politik 24 (4): 281-291.

Maryani E (2011) Media dan Perubahan Sosial. Bandung: Remaja Rosdakarya.

Masduki (2003) Radio Siaran dan Demokratisasi. Yogjakarta: Jendela.

Moleong LJ (1999) Metode Penelitian Kualitatif. Bandung: Remaja Rosdakarya.

Peraturan Pemerintah No. 11/2005 Tentang Lembaga Penyiaran Publik.

Sudibyo A (2004) Ekonomi Politik Media Penyiaran. Yogyakarta: LKiS.

Salman R (2011) Kajian yuridis: keberadaan lembaga penyiaran publik lokal sebagai badan hukum penyelenggaraan penyiaran. Dalam: Acara Seminar, 23 Februari 2011, Surabaya.

Santoso AB (2009) Perizinan LPP lokal di Jawa Timur: problematika dan solusinya. Dalam: Acara Seminar, 26 November 2009, Surabaya.

UU No. 32 Tahun 2002 tentang Penyiaran.

Wuryanta AG Eka Wenats (2006) Penyiaran publik dan public sphere. [Diakses 4 Oktober 2012] http://ekawenats.blogspot.com/2006/04/penyiaran-publik-dan-public-sphere.html. 